\title{
Turin in Transition: Shifting Boundaries in Two Post-Industrial Neighbourhoods
}

\author{
Pietro Cingolani
}

\section{Different Paths out of the Industrial Era}

Ethnographic studies on immigration carried out in urban areas in Italy share common features. These studies can be divided into two main groups: the "migrant focused" and the "space focused" (Cancellieri and Scandurra 2012). The first one takes specific national groups of immigrants as the unit of its analysis. This group is further divided into two: on the one hand, there are studies focused on the transnational dimension, which highlight the nature of multi-sited social relations of specific immigrant communities, with little or no attention to the dynamics of micro-territorial inclusion (Caselli 2009). On the other hand, there are studies that analyze specific national groups and their level of integration, paying attention to the perception of the presence of these groups among the natives (Carter 1997; Ceccagno 2007). These "migrant focused" studies give little value to intersectionality and have produced - even if unintentionally - an ethnic reification of social relations.

"Space focused" studies are based instead on the analysis of specific neighbourhoods and nearly all of them focus on poor and problematic neighbourhoods, in which levels of immigrant segregation and ghettoization are very high (Fava 2007; Pompeo 2012). For this reason there is very little available literature analyzing urban immigrants belonging to the middle class and living in the most affluent districts of Italian cities, exploring in depth the intersectionality across several dimensions such as gender, class and generation, and the link with processes of urban settlement.

The theoretical assumption of our study is to simultaneously assume a "space focused" and a "people focused" perspective, and to include in our sample not only

\author{
P. Cingolani $(\bowtie)$ \\ FIERI, Torino, Italy \\ e-mail: pietro.cingolani@ fieri.it
}


the immigrant population and poor and problematic neighbourhoods. Ceteris paribus, people with the same migration background can build different social relationships in different neighbourhoods of the same city; likewise migrants and natives behave in the same way within the same neighbourhoods. Following the methodological assumptions presented in the first chapter we used the level of diversity rather than the degree of disadvantage as the key criterion for selecting neighbourhoods - both deprived and affluent - with different shares of foreign residents. ${ }^{1}$ Looking at the growing literature around the concept of super-diversity, we can say that this concept has been coined to describe capital cities such as London, New York and Paris. Although provincial cities across Europe are increasingly characterized by a diversification of diversity (Berg and Sigona 2013; Erel 2011), the concept of super-diversity can be applied less to cities like Turin, where the level of diversity is lower. From the demographic, socio-economic and even ethnic point of view, Turin's neighbourhoods are more homogeneous than neighbourhoods of other European cities. In this perspective, we have chosen neighbourhoods where the processes of social change are more pronounced than in other areas of the city.

In the same city and also in the same neighbourhood we have observed multiple and contradictory paths to integration. As Gidley pointed out, integration is a situated and lived experience, 'a set of processes across a number of related, but ultimately autonomous, domains' (Gidley 2014). In the following pages we will try to explore these various domains in detail. To understand why social relations within these two neighbourhoods are different, we started with a theoretical hypothesis which sees social cohesion as a product of the balance between different factors.

There is a spatial factor, which concerns the urban structure of the neighbourhoods; there is a social factor, which concerns the socio-demographic characteristics of the population; there is a historical factor, which concerns the individual and collective memory, and last but not least, there is a subjective dimension, which concerns the agency of urban residents. Only by taking all these factors into account at the same time can we avoid every form of social and cultural determinism. Individual choices must be analyzed if we want to promote a non-mechanistic vision of integration which must be considered as a dynamic process (Brettel 2000).

In this sense, a micro perspective, based on ethnographic works is the only one that allows us to overcome simplistic analysis. That said, there are some structural

\footnotetext{
${ }^{1}$ We interviewed 29 experts (14 in Barriera di Milano and 15 in San Paolo) in the preparation phase for the ethnographic interviews between February 2011 and March 2011, in order to identify relevant aspects for the analysis of the neighbourhoods. Thanks to the information gathered, we identified ten interaction sites within the target neighbourhoods (squares, open air markets, roads, meeting centers). After that, we conducted 102 qualitative interviews with people who attend, live or work in the two neighbourhoods (56 in Barriera di Milano and 46 in San Paolo). In the selection of respondents we tried to balance the sample, taking into account gender, nationality, age and role. All interviews were conducted in the respective neighbourhoods at different locations (in the street, at homes, in restaurants etc.) between March 2011 and November 2011. Interviews were conducted in Italian, English and Romanian. We also interviewed 20 policy makers and stakeholders N10 in Barriera di Milano and 10 in San Paolo), aimed at reconstructing the policy perspective. Two neighbourhood forums were organized in Barriera di Milano and in San Paolo in April 2012 in order to discuss the first results with our informants, residents and stakeholders.
} 
factors that are very important in determining urban relations like the amount and quality of urban public spaces accessible in the two neighbourhoods. A good quality of life depends not only on the presence of public spaces but also upon their management and maintenance (Akkar Erkan 2007). Small public spaces well managed can meet people's needs more than wide, abandoned spaces. Social groups use spaces differently and at different times of the day. The more differentiated these uses are, the easier it is for conflicts between social groups to appear (Valentine 2008 and Webster 1996).

We also must take into account relations between neighbourhoods and the wider urban system. A high level of infrastructural and economic interconnection allows residents to choose where to perform certain activities and where to use certain services. An open neighbourhood attracts people from other parts of the city and promotes the circulation of resources and ideas, while a closed neighbourhood is like a ghetto, where inhabitants are encapsulated.

The historical memory of the people is another important factor. We wondered if inhabitants know about local history and if they bind their own individual biography to the history of the neighbourhood. A shared collective memory helps to increase the feeling of belonging to the territory and to reduce conflicts (Altman and Low 1992).

Turin is one of the Italian cities that, over the course of the twentieth and twentyfirst centuries, has seen the most significant demographic, social, and cultural changes linked to the arrival of foreign populations. After World War II, with the development of large factories, Turin witnessed the arrival of hundreds of thousands of workers from poorer, mainly southern Italian regions; from the 1980s onwards, with the post-Fordist transformation, immigrants arrived from around the world, the majority of them from Eastern Europe and Northern Africa. Often these new immigrants have gone to live and work in the same neighbourhoods that had welcomed immigrants from Southern Italy 50 years earlier, although this process did not occur in the same way and with the same results in all of the city's neighbourhoods. However, the socio-economic structure of the city has profoundly changed. If in the years of the great immigration from Southern Italy there was full employment and many immigrants worked in large factories, today unemployment rates are among the highest in the Italian cities. For this reason, Turin can be considered a unique laboratory for understanding social dynamics related to migration and integration, and the roles played by urban space and city actors in this respect.

The two selected neighbourhoods, San Paolo and Barriera di Milano, are located a few kilometres apart from each other. From a geographical point of view both neighbourhoods are very close to the city's historical centre but for different reasons they are both perceived by public opinion as being quite distant from it. The following map illustrates the location of the neighbourhoods within the city (Fig. 1).

Barriera di Milano is a former working class neighbourhood, located in the north of Turin. It is quite isolated from neighbouring areas by urban barriers: the Spina 4, the railway's track now undergrounded, runs along its western border; the northern border is marked by another dismissed railway and the eastern border is delineated by the cemetery. 


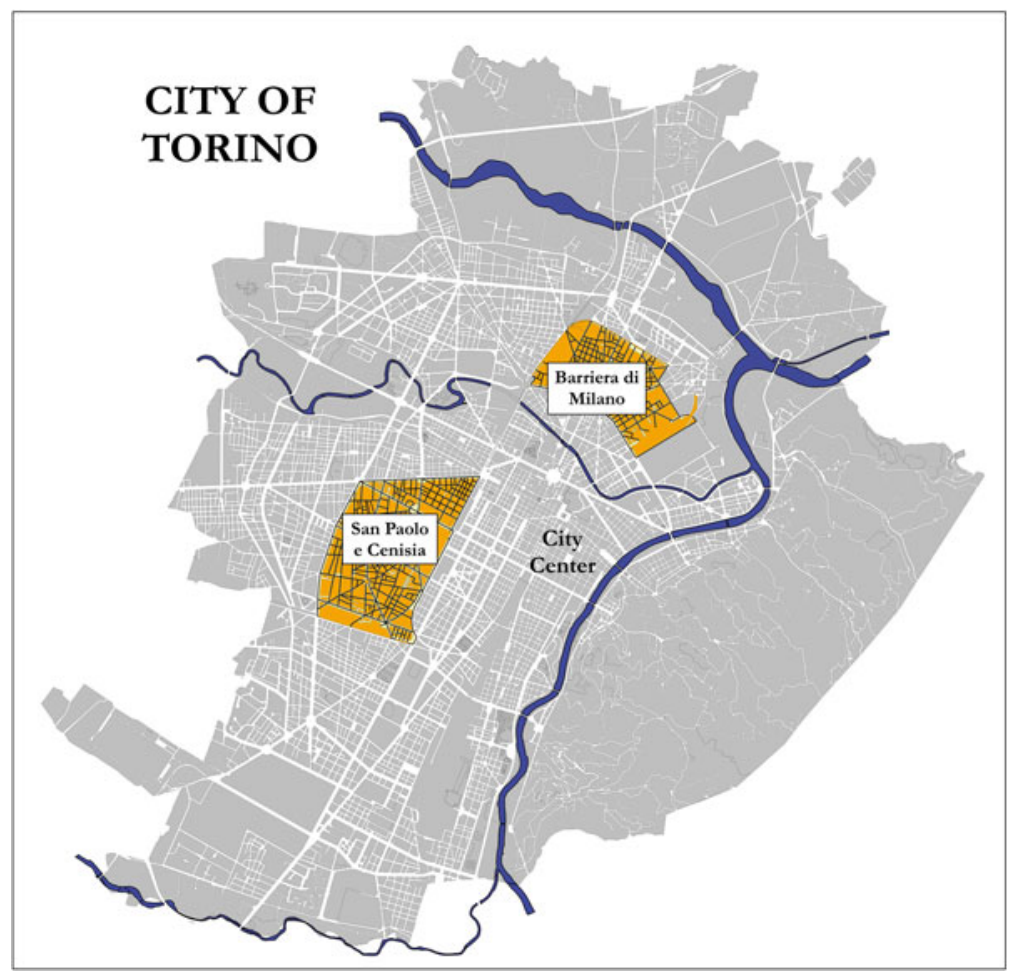

Fig. 1 Barriera di Milano and San Paolo on the map of the city of Turin

Table 1 Share of foreign population in Barriera di Milano (31 December) (City of Turin)

\begin{tabular}{l|l|l|l|l|l}
\hline Area & 2006 & 2007 & 2008 & 2009 & 2011 \\
\hline Barriera di Milano & 18.4 & 22.7 & 25.6 & 28.0 & 29.0 \\
\hline San Paolo & 9.5 & 11.2 & 12.6 & 13.5 & 14.0 \\
\hline City average & 9.4 & 11.4 & 12.8 & 13.7 & 14.2 \\
\hline
\end{tabular}

San Paolo is a service-oriented neighbourhood in the western part of the city of Turin. Its geographical boundaries are formed by four major roads: Corso Vittorio in the north, Corso Trapani in the west, Corso Castelfidardo in the east and Via Tirreno in the south. The older heart of San Paolo is Piazza Sabotino, the centre of the quarter both geographically and economically. It is also the point of departure of the quarter's main streets, which are developed in a star-like topographical way that is a very unusual feature for the city planning of Turin, where almost all quarters follow a grid plan.

If we consider the demographic characteristics of the two neighbourhoods, we can say that they are quite different. In Barriera di Milano the share of foreigners is $29 \%$ of the total population, much higher than the city average. This share has enormously increased in the last few years. In San Paolo the share of foreigners is lower, at around $14 \%$, which is similar to the city average, as shown by the Table 1. 
Table 2 Share of main nationalities of foreign residents in Barriera di Milano (1 January 2011) (City of Turin)

\begin{tabular}{l|l}
\hline Citizenship & $\begin{array}{l}\text { Share on } \\
\text { foreign } \\
\text { population }\end{array}$ \\
\hline Romanian & 33.2 \\
\hline Moroccan & 24.3 \\
\hline Chinese & 7.1 \\
\hline Albanian & 3.8 \\
\hline Egyptian & 3.7 \\
\hline Other nationalities & 27.9 \\
\hline
\end{tabular}

Table 3 Share of main nationalities of foreign residents in San Paolo (1 January 2011) (City of Turin)

\begin{tabular}{l|l}
\hline Citizenship & $\begin{array}{l}\text { Share on } \\
\text { foreign } \\
\text { population }\end{array}$ \\
\hline Romanian & 43.52 \\
\hline Peruvian & 13.90 \\
\hline Moroccan & 11.01 \\
\hline Albanian & 3.86 \\
\hline Moldavian & 3.01 \\
\hline Other nationalities & 24.64 \\
\hline
\end{tabular}

If we consider the nationalities of foreign residents, Barriera di Milano is more heterogeneous: there are more than 40 nationalities there, a third of them are Romanians, nearly one fourth Moroccans and one fifth Chinese (Table 2).

San Paolo is less diverse in terms of the national origins of foreign residents. A peculiarity of this area is instead the presence of a large Peruvian community, the most numerous in the city (Table 3 ).

The two neighbourhoods share a working-class history and a strong political mobilization that created social cohesion and a strong local identity as well as promoting the positive inclusion of internal immigrants in the 1950s and 1960s. The subsequent history of the post-industrial urban transformation has been very different in San Paolo and Barriera di Milano. In the first neighbourhood the conversion process happened quickly and can now be considered to be completed. In the second neighbourhood, however, this process is just beginning and remains uncertain because of the current economic crisis.

Today new immigrants arriving in San Paolo and Barriera di Milano are confronted with very different urban and socio-economic contexts characterized by different views about immigration, inter-group relations, types of conflicts and resolution.

We have organized the chapter into four parts. The first part of the chapter is devoted to presenting images of the two districts as they emerge from the descriptions of the residents: San Paolo is a peaceful urban village, with well-integrated families and little conflict; Barriera di Milano is a ghetto full of contradictions and poverty, with tensions that pit immigrants against the native residents along ethnic as well as intergenerational divides.

The second part of the chapter switches to a more detailed description of urban spaces, with particular attention to public areas, which analyzes their accessibility, 
the presence of specific services, and their ability to include and address the needs of different social groups.

The third part is devoted to an analysis of a few cases of conflicts: in Barriera di Milano, although problems are often traced to the presence of immigrants, it is clear that they are often generational conflicts regarding the use of space. Even the elderly residents who have organized themselves into spontaneous committees to combat drug dealing denounce the passivity and lack of interest among young natives. In San Paolo one of the few social problems of the neighbourhood involves groups of young Peruvian immigrants; here, however, the problem was solved by a mobilization within the Peruvian community which has minimized the involvement of institutions and the native population, lowering the threshold of ethnic tension.

In the last part we will return to Barriera di Milano to analyze how cooperation between different social groups can develop within 'zones of encounter,' spaces in which people develop lasting relationships based on participation in joint activities (Wood and Landry 2007). We will see how, in a multifunctional space that has been one of the specific contexts of our ethnographic observation, people of different ages, social and cultural backgrounds meet, get to know each other, and produce new forms of cooperation that challenge preconceived identity barriers.

\section{The Residents' Voices}

\section{1 'The Village in the City': The Peaceful Image of San Paolo}

San Paolo is a relatively new neighbourhood in Turin which was located outside of the city's duty boundary until the end of the nineteenth century. This boundary was removed in the 1920s, but the railway still isolated the area because the tracks separated San Paolo from the rest of the city, keeping it socially, culturally, and politically isolated for a rather long time, so that it developed into a sort of microcosm with its own identity and social environment.

The actual building development of San Paolo took place after 1910 and was led by a high number of small, medium, and large industrial settlements in the area, mostly in the metallurgic, steel, and automotive sectors. With the heavy flow of internal (mostly rural) immigrants, San Paolo grew in every direction like a spider's web. The tendency towards isolation remained until after the Second World War, thereby reinforcing a strong sense of belonging to the neighbourhood within the population (Donna 2010).

This identity has been strongly linked to the neighbourhood's industrial nature. It has always been referred to as the 'red neighbourhood' for its deeply-rooted leftwing parties and the battles carried out for better working conditions. Both Catholic and secular groups in the local society have generally shared what Jalla (1978) defined as "utopian communism," which allowed them to create a compact alliance in the fight against fascism. 
According to Diego Novelli, a former mayor of Turin who has always lived in the neighbourhood: "San Paolo is a village deeply rooted in working class traditions. Socialists like Gramsci had a big following in the district. In addition to being working class, San Paolo also has a long anti-fascist and partisan tradition. Dante Di Nanni, for example, was an anti-fascist. In general, the unions were always full of people, the true reference points for the inhabitants of the area and beyond."

During the economic boom that followed the post-war reconstruction, San Paolo kept growing demographically and in urban development, while still preserving its working-class identity. As a symbol of this productivity, the Lancia skyscraper in Via Lancia was built between 1951 and 1956. Lancia was one of the main reference points for the life of the neighbourhood, not only because of the factory, but also because it developed many social activities, such as housing and recreational activities for employees, sporting infrastructures, summer camps for children, etc. (Calosso and Ordazzo 2009). The productive structures have generated strong social capital, both bonding (based on common belonging to the working class) and bridging (integrating internal migrants). It has primarily been families rather than individuals who have immigrated to the neighbourhood. Families decided to settle in this area because, in addition to the presence of the industries, there were many services for citizens. Since the 1980s, foreign immigrants have begun to arrive: mostly Moroccans, Romanians and Peruvians. This new phase, too, is comprised primarily of immigrant families. Their arrival has been greeted by the natives not as a rupture with the past, but as a strong continuity, as if it were a new chapter of a common history.

The inhabitants of San Paolo are fond of their neighbourhood and still live today as if it were a country town inserted into the city, where everyone knows everyone and where cultural differences are not perceived as problematic. The sense of belonging, solidarity, and social cohesion are themes that emerged in many interviews. In the words of many of the inhabitants, San Paolo is first of all a quiet place, clean, and well served by public transport, with schools, sports facilities and green areas, and where the sense of security is cushioned by good management of the territory not only by institutions but by the citizens themselves. This image is reaffirmed, especially in contrast to the problematic image of other districts of the city.

Many locals stress that the migratory tradition which has always characterized this neighbourhood has fostered its spirit of acceptance and openness to newcomers. Foreigners in San Paolo are described by Italian residents as 'working families, with a good level of education, internal organization, and social cohesion.' (San Paolo, Italian journalist, 26 years old).

The ones who fear and stereotype the newcomers tend to be shopkeepers and the elderly. Business owners mainly refer to the risk of excessive economic-productive competition, due to the opening of new businesses. Moroccans, along with the Chinese and Romanians, are considered immigrants with great entrepreneurial spirit and are often portrayed as aggressive and unfair competitors.

A shopkeeper in Piazza Sabotino said:

The Moroccans open and run shops and other venues or lease licenses to market stalls. Many Italian shops in via Di Nanni or in the square are closing and many Arab stores are opening, especially food and phone centres. (San Paolo, shopkeeper, 45 years old, M) 


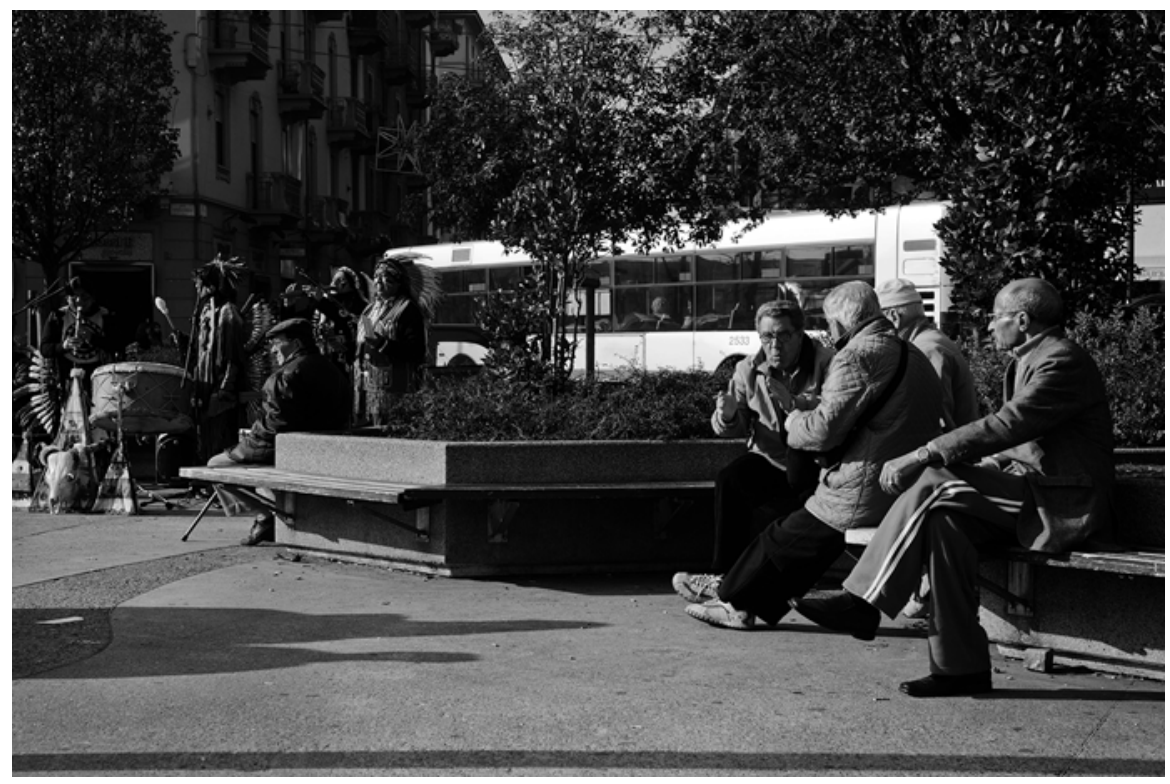

Fig. 2 Rotonda Frejus. Pensioners and migrants (Photo by M. Pinto)

In an area with a high commercial vocation, foreigners frighten residents not because they are involved in criminal activity, but because they are considered 'too' assimilated; they have learned the rules of the place so well that they have become dangerous competitors.

The elderly, in their discussions, are especially alarmed by the different use of public spaces. Nevertheless, while they underscore the tensions related to the presence of foreigners, at the end of their narratives they often change their accusatory tone to a much more inclusive and open attitude towards the often harsh living conditions endured by immigrants. With some compassion they admit that the Italians themselves often take advantage of foreigners by employing them in strenuous, dangerous, and poorly paid work (Fig. 2).

Those who work at the market stalls, for example, are all underpaid. They come to work practically for free. Whoever takes a stall pays a lot of rent, works like a mule, and pays taxes. Before recouping their expenses they must spit blood. In addition they pay the rent on their house. They should be admired! (San Paolo, pensioner, 76 years old, M)

When the natives of San Paolo speak of the immigrant presence, they often tend to emphasize a gradual and reassuring assimilation. A shopkeeper in the covered market, speaking of Moroccans, makes an interesting comparison between those who arrived in Italy in the 1990s and those who have come in the last few years:

The Moroccans who arrived in Italy 20 years ago were very different from those who arrived in recent years. Whereas before this group was particularly involved in petty criminal activities such as drug dealing, now the Moroccans tend to come with their families, to perform honest work and try to fit into the Italian culture. In general, the influx today seems 
more sound. There is a better relationship between 'us' and 'them' even though the cultures are very different. (San Paolo, shopkeeper, 45 years old, M)

Even from the immigrants interviewed, a peaceful and non-confrontational vision of inter-group relations emerges. An Albanian man who arrived in the neighbourhood in 2002, explains:

The whole area is very quiet compared to other neighbourhoods such as Barriera di Milano and Porta Palazzo. Those areas are not very clean and the people are poorly educated. The immigrants are too concentrated. In those areas there is a lot of drug dealing and crime and law enforcement agencies do not control it; they close their eyes and pretend nothing is happening. The dealers, however, have no other choices. ... Many foreign families live in this district and this creates fewer problems for society. Whoever has a family like me has a lot more responsibilities. ... I know a lot of Italians, Albanians, Romanians, and Moroccans. They are all people who are working or looking for work like me. They are not people who want to break the law and many of them are planning to settle in this area. I know that many people want to buy a house with a mortgage. I personally have never heard of intolerant or violent attitudes in our encounters. (San Paolo, unemployed, 56 years old, M)

In a meeting held with residents to discuss the problems of the neighbourhood (the 'Neighbourhood Forum' described in the Introduction), none of the participants raised the aspect of interethnic relations. Foreigners and locals, however, agreed with each other in lamenting the lack of parking, poor street lighting, and the early closing times of supermarkets. Such a peaceful image of the relations between natives and immigrants is also found in public discourse conveyed by the neighbourhood policy community and media, exemplified, for instance, when political refugees squatted the San Paolo Clinic (see chapter "News Media and Immigration in the EU: Where and How the Local Dimension Matters"). Actually, one of the few situations which in San Paolo has raised concerns and alarm among residents is the presence of gangs of Peruvian teenagers who made intensive use of public gardens, often quarrelling violently with each other. In this case senior members of the same Peruvian community intervened to resolve this alleged social emergency - a very different situation from what developed in Barriera di Milano.

\title{
2.2 'We are the People of the Ghetto': Stigma and Pride in Barriera di Milano
}

\begin{abstract}
I do not know exactly where my neighbourhood begins and where it ends. But I know that Barriera di Milano is seen by many people as a ghetto. We are the people of the ghetto, because there are many poor people here, there are 17-year-old kids who live in homes alone, without parents; for me it is a ghetto because there are more poor people than rich ... I see Barriera this way, but I would not leave it for anything in the world. (Barriera di Milano, rapper, 19 years old)
\end{abstract}

These words of a 19-year-old immigrant of Moroccan origin are representative of the perception that many Barriera di Milano residents have of their neighbourhood; here the recent immigration has been accommodated differently and has 


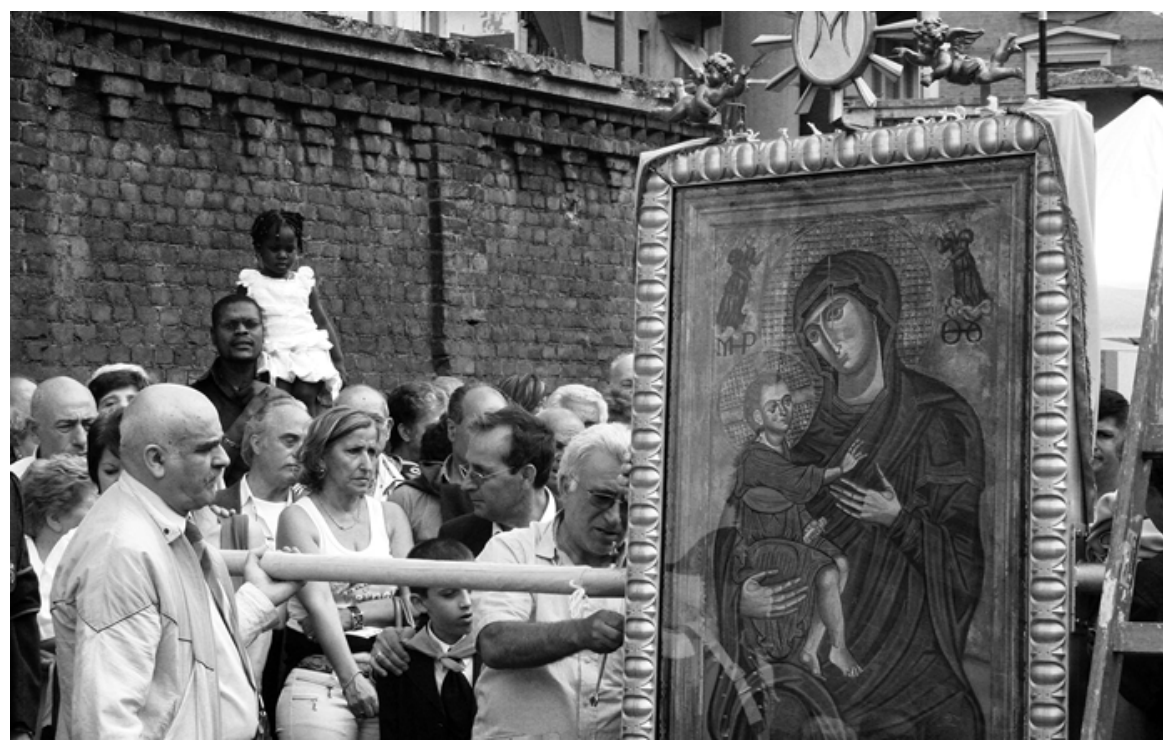

Fig. 3 Piazza Foroni. Religious procession for Holy Mary of Cerignola (Photo by P. Cingolani)

produced very different reactions than in San Paolo. In recent years, Barriera di Milano has experienced great social and economic transformations. To understand what Barriera di Milano is today, however, it is useful to reconstruct its history through the memories of the oldest residents.

Like San Paolo, the neighbourhood started to develop in the second half of the nineteenth century as an unplanned built-up area outside of the toll gates, i.e., passages that ensured the payment of the duty by those who entered the city. This is the origin of the name "Barriera di Milano" (Toll Gate of Milan). From the end of the war through the economic boom, a rapid urbanization process started at the expense of the residual rural areas: from 1951 to 1963 more than 7,000 apartments were built. However, the land use plans were approved late, when the building process had already ended. The consequence was disorganized urban and housing growth and an underdevelopment of services and public spaces (Beraudo et al. 2006).

The first big increase in immigration took place during the economic boom of the late 1950s and 1960s, with large inflows from Southern Italy and substantial transfers from other city areas induced by the increasing demand for labour and the rapid expansion of housing (Beraudo et al. 2006).

These immigration flows produced structural and long-lasting effects. The signs of internal migration are still visible in the urban landscape, where streets have names of villages in Southern Italy and open markets and shops sell goods from those regions, such as in the area of Piazza Foroni, where a large community from Apulia is settled (Fig. 3).

In the past many people both lived and worked in the neighbourhood and this created close-knit social networks. It was a closed urban system (Wallman 
2003) in which the inhabitants tended to share many symbolic and material resources. According to a pensioner who had worked in Barriera di Milano for more than 20 years:

Once upon a time there was a big factory, you worked for the great Fiat motors and then found your house not far away, in the same neighbourhood. Besides the large factories, there were many small workshops making mechanical parts in the courtyards of the houses. They remained until the 1980s when the neighbourhood converted to an almost exclusively residential one. Then people looked for homes close to work for two reasons: because it was cheaper and because transportation to the rest of the city was not well developed. You made friends with colleagues from work, who could also be your neighbours and then you also spent your free time with them. (Barriera di Milano, pensioner, 76 years old, M)

Even after World War II, Barriera di Milano, like San Paolo, was described as a village within the large industrial metropolis. The notion of 'We southern immigrants' has been important in defining the identity of the neighbourhood. But in Barriera di Milano, unlike San Paolo, this 'we' is currently almost always being used by the natives to oppose the new immigrants. Many senior residents from Mezzogiorno do not hide the difficulties and prejudices they themselves encountered, yet they are the first to criticize the newcomers.

Memories of the past in Barriera di Milano are very divided. People today still have the perception of being marginalized from the rest of the city. While the sense of marginality in the past was offset by a strong internal identification, today they are living in a much more fragmented way, with no points of reference:

I was born and raised in Barriera di Milano. Once we kids said, 'we are from Barriera,' and we had our gangs. For us it was a point of pride when you came from the neighbourhood. Then there were those of Falchera, Vallette, Via Artom [other working-class neighbourhoods with high internal immigration]. We bumped into each other in clubs and the mess broke out there. And we had to uphold the name of the neighbourhood. (Barriera di Milano, unemployed, 54 years old, M)

The most recent immigration is often associated with images of disorder and chaos. Many speak of a real invasion, a slow process of population resettlement from Porta Palazzo, the district which first saw the arrival of immigrants, to Barriera. Often this invasion "from the outside" is accompanied by a picture of invasion "from within." The native people are noticing a growing demographic imbalance between themselves and immigrants, mainly related to higher fertility rates among foreigners:

There are more and more of them here, not only because they come from outside, but because they have more children than we Italians. When I see these Moroccan moms with all these children I worry and I think that soon we will be overwhelmed. My son is thirtyfive and not yet married! (Barriera di Milano, barman, 54 years old, M)

In Barriera di Milano, where many live with precarious housing and employment conditions, competition is particularly strong. "We" impoverished and unprepared Italians are contrasted against "their" united and well-organized immigrant solidarity in sharing information and "stealing" public resources.

Foreigners are also accused of not respecting social rules and cleanliness, silence during the night hours, or traffic regulations. The most recurrent theme in the 
narratives of the Italian population is the link between immigrants and crime, especially petty theft, pick-pocketing, and the drug trade. This link is often found in newspapers and the local media and has produced a stereotyped and degraded image of Barriera di Milano. ${ }^{2}$

The difference between "us" and "them" is not exclusively based on ethnicity, but also reflects length of time in the neighbourhood. Immigrants who arrived earlier are the most widely accepted because they are believed to be better adapted to a specific model of social order, an urban way of life based on control, decorum, and work ethic (Wimmer 2004). On the contrary, newcomers are perceived as nonintegrable. A barber from Apulia reflects upon his Moroccan customers:

There used to be many Moroccans, but even they are leaving the area. They were my clients up until 2000. They worked in the mechanic workshops, in trade. Everybody worked. They went away to get themselves out of delinquency. They were solid people, who could improve the area. But just like many Italians they wondered 'why do we have to stay here, we'd better go!' And then new ones arrived, the real desperate ones, those who are willing to do anything because they have nothing to lose. (Barriera di Milano, barber, 55 years old, $\mathrm{M}$ )

Even in the narratives of immigrants, cleavages emerge related to the time of their arrival in the neighbourhood. Earlier immigrants offer evidence to differentiate themselves from later groups of immigrants, with whom they associate behaviour that contradicts the social order. For example, among Senegalese immigrants (Castagnone et al. 2005):

Among us Senegalese much has changed. The marabout [Spiritual leader among Senegalese Mourid Muslims] say it is not good, because drugs ruin those who use them and who sell them; it is against religion. Many young people do not listen to the elderly people and they have also moved away from the Dahira [Local organizational structure of the Mourid brotherhood]. Now it's not like when my sister arrived, then they helped us a lot. There are guys who get together in small groups and only run at night. There are many young people who take things and do not give back. They do not try to learn the language or get closer to the Italians, as I did. (Barriera di Milano, student, 28 years old, M)

These internal differences are also reflected in the geography of the neighbourhood and the ways public spaces are used. There are areas described by earlier immigrants as more "decent" and "respectable", that correspond to the ideal of social order into which they want to insert themselves, and areas from which they want to keep a distance, both physically and symbolically. A good example is the Porta Palazzo market. For many immigrants who live in Barriera di Milano the market has been and continues to be a key reference point where they build social networks, find information, and make purchases (Semi 2006). But Porta Palazzo is also a site of disorder, increasing crime and insecurity. Moving away from that location means asserting one's own social respectability in front of Italians as well as

\footnotetext{
${ }^{2}$ Barriera di Milano is not new to the phenomenon of social deviance; petty crime today is nothing in comparison to the 1960s, when armed robberies, burglaries, and shootings were common. Even the problem of drug dealing and drug use today has a much less dramatic profile than in the 1970s and 1980s, when many families lost their children due to heroin overdoses. Nevertheless, both petty crimes and drug dealing remain significant compared to other city neighbourhoods.
} 
your countrymen. According to a man of Moroccan origin, who has lived in Italy for nearly 20 years:

Porta Palazzo is an area of transit, even in France it is known, even out in the world, everyone says 'at Porta Palazzo'. There you will find everything for your business, if you need to meet a friend you say, 'I'll see you at Porta Palazzo.' But I must admit that I would never live in Porta Palazzo, there is too much personal discomfort and in recent years I stopped going. There are these desperate young people. We had a serious mentality, but these people are different. And not only Moroccans. There is everything, Senegalese, Romanians, Tunisians, Algerians. (Barriera di Milano, workman, 52 years old, M)

\section{Urban Spaces and Social Management}

\subsection{The New Birth of the San Paolo 'Village'}

San Paolo was the subject of conversion and regeneration policies long before Barriera di Milano. In San Paolo in the 1990s the abandoned industrial buildings began to be torn down and replaced by housing and service complexes. In the southeast part of the neighbourhood, for instance, we can find a former tire plant which is now the well-known Sandretto Re Rebaudengo Foundation for contemporary art, established in 1995. A former automotive components factory was completely converted into the Urban Eco Museum. In this area of the neighbourhood we can also find a Health Unit, Social Services and the Giardini SPA, which has many services for children, teenagers, and elderly people (Fig. 4).

In San Paolo services and meeting places are rather evenly distributed since they are located not only in the newly constructed areas but also in the older heart of the neighbourhood. One of the most popular youth meeting points in the area is the San Paolo Salesian Parish Recreation Centre; this centre hosts an average of 2,000 people every week, many of them from Morocco, Albania, Romania, South America and Pakistan. It is a meeting point for the youth of the area because of its large sport facilities, and the educational and training courses it offers (Calosso and Ordazzo 2009).

Behind the oratory there are numerous services for public use, such as the Permanent Territorial Centre for adult education, which offers courses for school diplomas, as well as brief courses on specific subjects (foreign languages, computing) and job counselling. The majority of the users of this centre are foreigners, with a high proportion of women migrants. Commercial services, which are, in general, quite numerous in this neighbourhood compared to the city as a whole, are concentrated in the central area. Probably the strongest commercial area outside the city centre of Turin is located here, with its branded stores, historical shops, and entrepreneurial activities, including those run by minorities of migrant origin which have developed during the last five years. Aside from the commercial streets, there are three big open-air markets. The market of Corso Racconigi is the most important and popular in the area. Two kilometres in length and with 370 stands, it is the second largest market in Turin and allegedly 'the longest one in Europe'. 


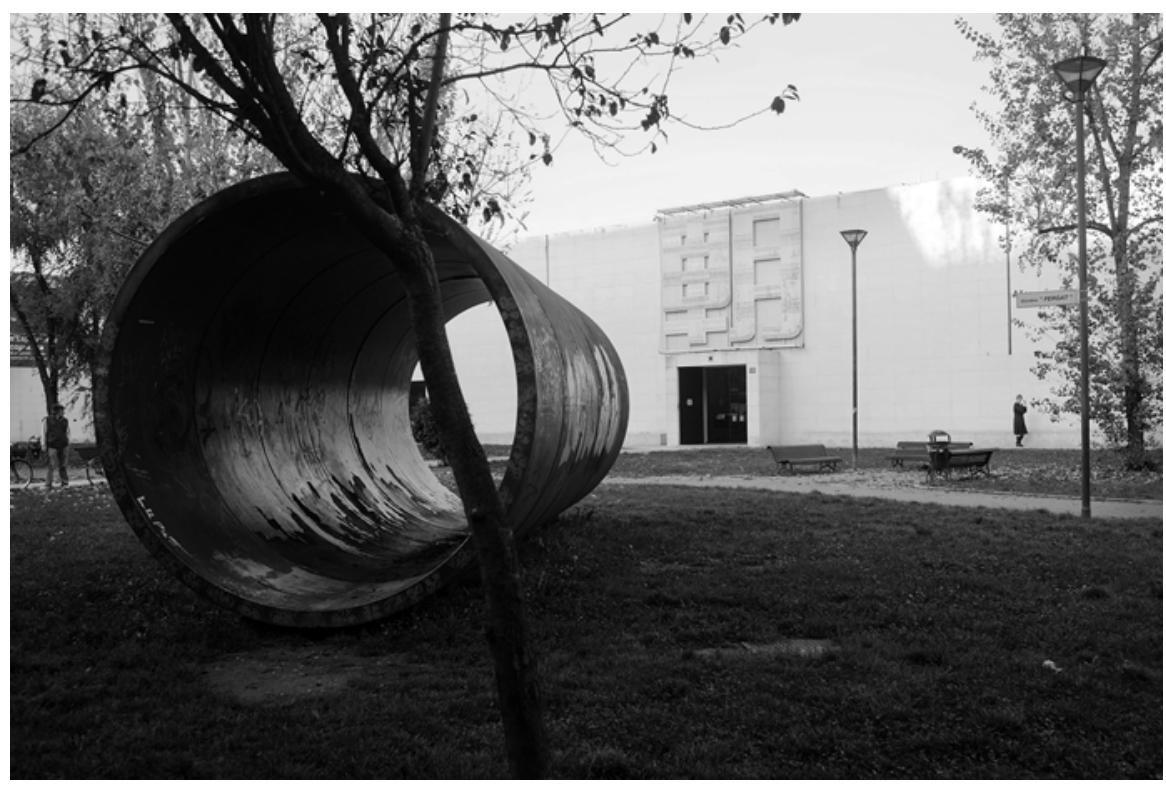

Fig. 4 Sandretto Re Rebaudengo foundation (Photo by M. Pinto)

Another asset of the neighbourhood are its public parks, the result of the redevelopment projects implemented in the district from the 1980s to today. The neighbourhood has many green spaces, gardens, and playgrounds for children and sports. Public gardens, in Turin's history, have always been a fundamental space for creating social cohesion, because of their accessibility to all categories of people and openness to many different uses. A basic condition for the maintenance of this function is management of the space in a way that mediates conflicts between different users and supports social and cultural diversity (Low et al. 2005). In this regard, an educator emphasizes:

We need to promote and enhance the use of public spaces such as gardens. Because public spaces are physical places that belong to both no one and everyone. At one time the public spaces were much used. Because people stayed in the neighbourhood more, in the summer there was no air conditioning in homes, we went out more.... Now use of the gardens has changed, immigrants appeared, but Italians resist them as they perceive these spaces as their own, even if they were no longer using them. (Barriera di Milano, association president, 32 years old, M)

The Giardini SPA are clean, safe, and frequently used by residents; they are not very large but are well served. There is a play area for children, two basketball courts, tables where you can play cards, an area reserved for dogs, and a kiosk selling drinks and sandwiches. The various groups use the space separately. During the morning hours it is mostly seniors who use the space. They usually gather on the same benches to chat and discuss the news. In the afternoon, in addition to pensioners sitting on "their" benches, in the area used for children's games there are many Italian and foreign mothers who bring their children to play. The relationships are 


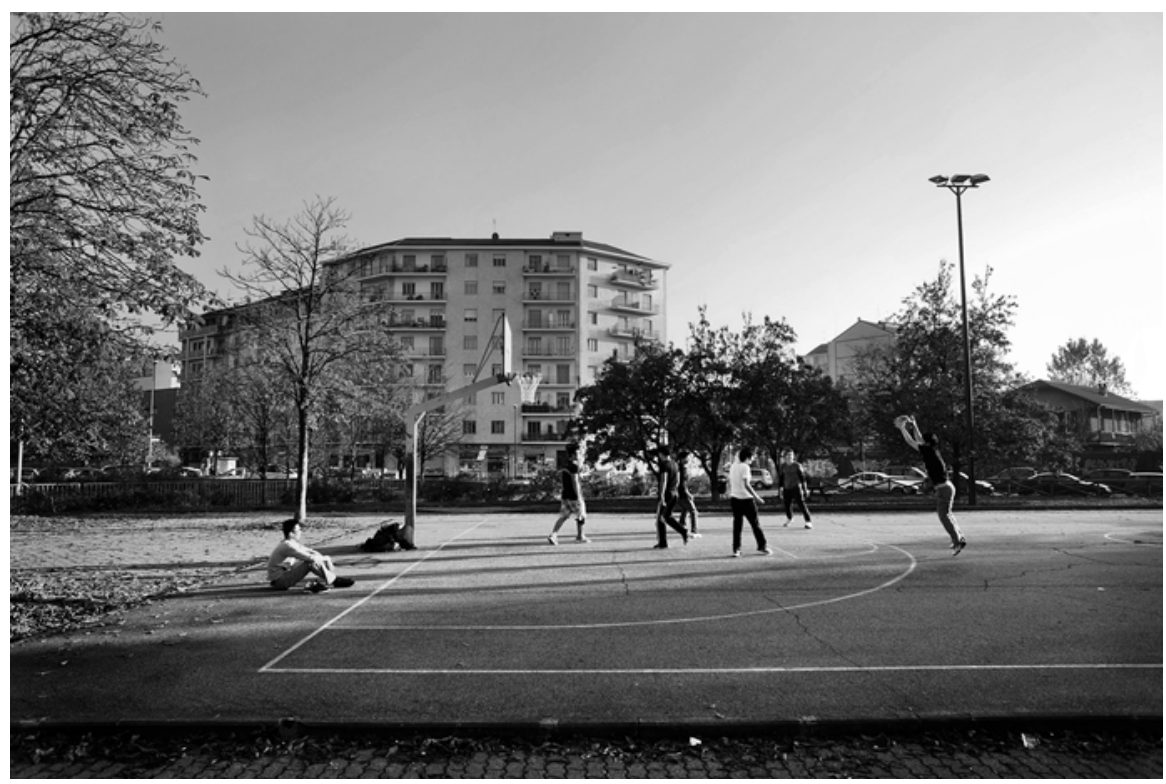

Fig. 5 Giardini SPA (Photo by M. Pinto)

very friendly and the mothers of different nationalities chat and exchange advice regardless of their various origins. A Romanian mother stated:

We have all known each other for some time. We do not care about our origins, because our children play together without thinking about where their parents come from. (San Paolo, secretary, 39 years old, F)

The basketball courts are used by many young people, both Italian and foreign, and especially by Moroccans, Romanians, Egyptians, and Albanians, but also by young Chinese. As a 27-year-old man explains (Fig. 5):

Sport is an excellent vehicle for relations and integration between the various groups. At best, you fight for the ball or over a foul but never for any other reason. (San Paolo, student, 27 years old, $M$ )

A young Moroccan man who arrived in Turin in 2004 says:

In the summer and in the afternoons there are always people who go to Ruffini Park to play football. There is no drug dealing or anything in either the gardens or the park. They are quiet places and always full of people. (San Paolo, student, 19 years old, M)

The tables where you can play chess or cards are used primarily by older people and, in the evening or on weekends, by Romanian men who meet to drink beer. The relationships between Italian pensioners and Romanian men are sporadic but friendly, as explained by one of the former:

We all live in this area and the spaces must be for everyone. The important thing is to respect each other and respect the public space. In addition, as we know, in the city there are not a lot of green spaces and those that exist must be available for all patrons without distinction. (San Paolo, pensioner, 78 years old, M) 
In the evening the garden is frequented almost exclusively by young people. The various ethnic groups divide themselves into different zones. Each group has its own bench or table of preference from which it rarely moves. In this case the groups scarcely communicate. There have never been clashes, quarrels, or scuffles here and interactions, although rare, are still described as being relaxed and friendly.

In general, the relations between the different groups of users of the garden are rare and sporadic but never antagonistic. Each group (young Italians, retired men, Romanians, etc.) is usually in the same area or on the same benches, almost as if there were an unwritten, but implicit agreement by all on how to handle the public spaces.

\subsection{Barriera di Milano, a Never-ending Construction Site}

In Barriera di Milano the urban fabric looks much more fragmented than that of San Paolo. Over the years the relationship of residents with their neighbourhood has changed significantly. In recent decades the percentage of residents who use it as a dormitory area has in fact increased because many more work and spend their free time elsewhere. Barriera di Milano has been impacted by changes that have also occurred in many other European cities, i.e. a shift from a traditional model, where the inhabitants worked, lived, and ate all in the same neighbourhood to new models in which these functions are separate; more or less dense groups of individuals have appeared who frequent the city to varying degrees in order to pursue equally differentiated activities (Martinotti 1993). ${ }^{3}$ We can also relate the use of the neighbourhood by the inhabitants to specific modes and types of urban and architectural interventions. For instance, the disappearance of large industrial factories has left gaps in the territory which certainly affect how the inhabitants live the city.

The last building wave started after major changes to the land use plan were adopted in 1995 and it is still ongoing. It included the construction of new public housing settlements in the abandoned industrial sites (Fig. 6).

However, the share of public housing in the neighbourhood has remained lower than the city average: in the city it is $3.9 \%$, while in Barriera di Milano it is only $1.8 \%$ (Cooperative Progest 2008). Compared with other de-industrialized neighbourhoods in the city, urban regeneration has been limited in Barriera di Milano. This was also due to the above-mentioned small public housing stock and highly fragmented private home-ownership, both of which have strongly hindered the local administration from taking action (Ciampolini 2007). The result is widespread urban blight and low-quality housing stock. Furthermore, welfare services are

\footnotetext{
${ }^{3}$ Martinotti identifies different types in the cities - from traditional types, to first, second, and third generation - and he matches the appearance of urban populations with different characteristics: the people who live, work and consume in the same part of the city; the commuters who work and sometimes consume; the city users who consume; and finally the metropolitan businessmen who work and consume.
} 


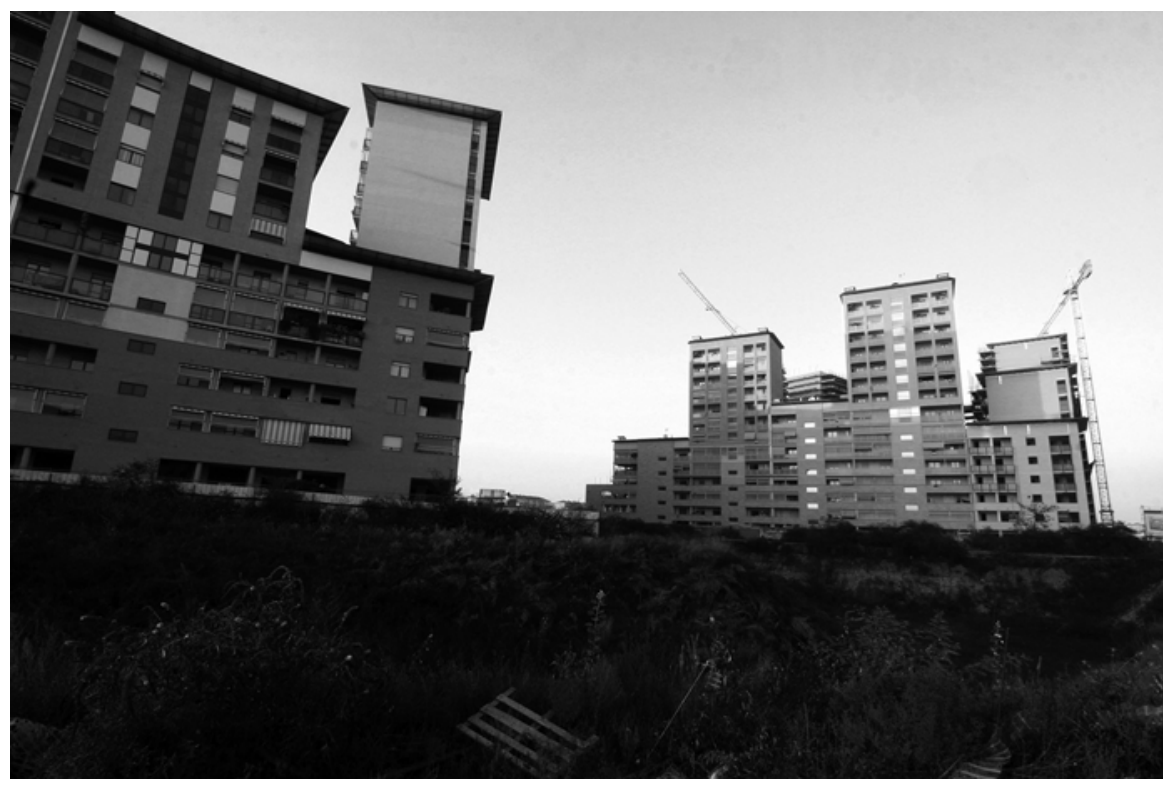

Fig. 6 New housing settlements in Via Cigna (Photo by P. Cingolani)

unevenly distributed and mainly located in the eastern part of the neighbourhood, which is not easy to reach. Social services and schools (especially preschools) are few and insufficient if we consider that Barriera di Milano has a density of population and a proportion of poor families and young people higher than the city average. Moreover, there is a lack of meeting spaces and premises for non-profit organizations and cultural and recreation activities, so that their location depends more on the availability of space than on the distribution of demands and urban planning (Ascolto Attivo and Zaltron 2010).

Another major problem of Barriera di Milano is the lack of green spaces. This is the consequence of a particular urban history, with the oldest zone densely built around narrow streets, with very few squares, no green space and a lot of disused industrial areas. The average amount of public green space available to each inhabitant of Barriera di Milano is 1.64 square metres, much lower than in the city, where it is 20.13 square metres. Public gardens are few, small, ill-equipped, and their use has changed over the years. Today, they are primarily used by residents who are not able, due to time, mobility or economic resources, to spend their free time outside of the neighbourhood. There are many elderly people who do not have a car or are unable to move independently, as well as many immigrant mothers with young children who live in small apartments with no yard. A typical example is that of the gardens of Via Montanaro, a narrow strip of land, located between two busy roads. The gardens are surrounded by a wall and an abandoned building that block the view and make it difficult to access from one side. There are just a few, dilapidated benches (Fig. 7). 


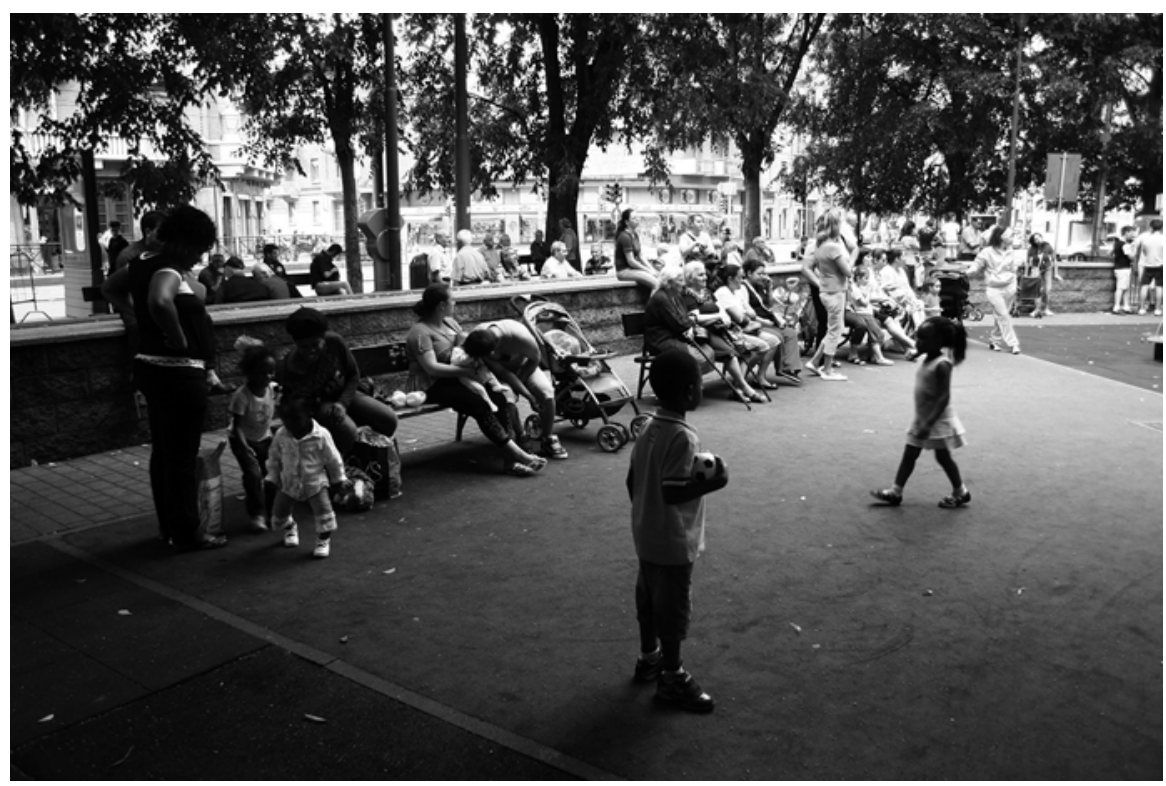

Fig. 7 The gardens of Via Montanaro (Photo by P. Cingolani)

The different categories of users who frequent the gardens have very different perceptions. A visible discomfort and a sense of disorientation often emerge among the elderly Italians in contrast to a sense of self-confidence among immigrants. Dirt and litter is a sensitive issue and it is almost always attributed by elderly Italians to the supposedly uncivilized behaviour of immigrants, who even accuse the latter of urinating in the corners of the gardens. The senior citizens also experience discomfort due to the presence of groups who are appropriating specific parts of the gardens exclusively for their own use. These are young Romanians of various ages who have met for years in a section of the gardens around the ping-pong table. They talk to each other, listen to music, play cards or video games. The young Romanians emphasize their sense of belonging and the role of social control they exercise in these public spaces. However, in the eyes of some Italian residents this presence has become so disturbing that they have asked for checks by the police for alleged drug dealing activities. The owner of the tobacco shop that overlooks the gardens attributes petty thefts in the neighbourhood to these men, although he cannot provide any proof to support his allegations. Other residents of the area underscore, on the other hand, how the presence of these young people - who live in the neighbourhood and are known by all - in fact constitutes a defence of the territory that has marginalized other disturbing presences, such as drug dealers and addicts.

In the gardens of Via Montanaro there are conflicts between the elderly and youngsters, natives and immigrants. During the fieldwork we met a group in the gardens that is committed to crossing social boundaries. It is an association that provides employment for people with mental illnesses. The members organize 
games with the kids and clean the grounds of the gardens. Italian and foreign mothers show confidence in these individuals, know them, and often put their children in their hands. Even the elderly Italians are turning to this group to report the problems present in the gardens, such as a broken street lamp, a damaged bench, or garbage abandoned in a corner.

Their neutral position, outside the established social boundaries, makes this group particularly suitable for the resolution of conflicts that may erupt between those who frequent the gardens. The positive effect that this group has on the relationship in the park is also linked to the cleaning job. What is important to the development of cooperative relationships, in fact, is not just the amount of public spaces available, but also their quality.

\section{Daily Conflicts in Public Spaces}

\subsection{Young Versus Elderly in Barriera di Milano: The Fight Against Drug Dealing}

Analysis of the conflicts in Barriera di Milano often reveals that the opposing parties are different not so much because of ethnicity but because of age. The phenomenon of drug dealing in Barriera di Milano is highly visible and has prompted some elderly Italian residents to mobilize and develop self-organized patrolling strategies. Almost every night they walk the streets hanging out in small groups with the aim of intimidating the drug dealers. It is not hard to find them between 9 and 10 o'clock around the gardens of Via Montanaro and in the narrow streets that wind through Corso Giulio Cesare and Via Cigna, in the western part of Barriera di Milano. These old men have different regional origins; they are from Apulia, Calabria, and Piedmont. They belong to different social classes and also claim different political affiliations. In general, they are very dissatisfied with politics that have proved unable to tackle what they perceive as the 'real problems' of everyday life. Their group was formed through spontaneous congregation:

The strongest recent change in Barriera has been immigration. So many people come here to commit crimes. We found ourselves with drug addicts and drug dealers on the doorstep. It all started here in 2007. We formed spontaneous groups, we met in the evenings, we were a group of people who did not know each other, we looked at each other from the balcony and we did not know what to do. One evening, exasperated, I threw an orange from the window on the heads of some African children, to chase them away. After the first contact a group of 15 people was born. (Barriera di Milano, pensioner, 64 years old, M)

After they gathered these men began to patrol the streets. The strategy adopted was to approach alleged drug dealers, to draw attention to them with shouts and insults, and to threaten to call the police. Young people, especially Nigerians, moved away immediately and a chase would begin through the streets of the neighbourhood. There were also small fights, because some of the elderly residents carried sticks. On more than one occasion these seniors raided the shops of Africans that 
were considered centres of criminal organizations which resulted in nothing but furious quarrels with the owners. In 2010, the members were given a more structured organizational form, with a charter, a secretariat, and specific internal functions and they became part of a coordinated network of spontaneous committees in Turin which deal with similar situations in the various districts of the city. In December 2010, the committee staged a candlelight vigil against drug dealing on the streets of Barriera di Milano. The objectives of their battles were extended to other topics related to the protection of safety, with the collection of signatures against the opening of a new Islamic prayer hall (i.e. not a proper mosque) in the neighbourhood, which they consider a serious danger to residents. The foreign presence is regarded as not just a material threat but also a symbolic threat to the neighbourhood's identity.

The members of the committee accuse other elderly residents of having abandoned the area out of resignation. More than once, they have criticized them because they remain closed up in their houses. Young Italians are not spared criticism either:

Young people do not participate in the committee, because they have other ideas, they just want to go and have fun. We are all senior citizens. Thirty years ago it would have been entirely different, when we were young and strong we would have sat in a group and made all these blacks disappear by force! Now young people are not at home, they get drunk and do not participate at all. (Barriera di Milano, pensioner, 64 years old, M)

What emerges, once again, is a strong generational divide, with grandfathers who say they are rooted in the neighbourhood, and children and grandchildren who appear passive and unconcerned.

The story of the candy store "Shenanigans" is another example of intergenerational conflict. The few Italian shops that remain in Barriera di Milano today have lost the role that they played in the past as places to meet and socialize. In 2009, a young woman opened a candy and garments store. In a large room with shelves full of sweets she also put a ping-pong table, a computer with an internet connection, and a play-station. The store began to attract many teenagers from the neighbourhood, both Italian and foreign-origin, who spent whole afternoons there. The kids talked with the owner about their problems, some carried out tasks and helped out in a self-organized after-school activity. Even parents started turning to the owner to learn about their children's problems and concerns. On some summer days, up to 50 people gathered in the store. The store's website has become a virtual space where photographs of the young customers are uploaded, along with their thoughts and dreams for the neighbourhood. Since June 2011, these thoughts have also been merged into a serial novel, which chronicles the lives of six young people in the neighbourhood, Italians and children of immigrants. The presence of the store and young people, Italians and foreigners, however, has sparked anger among neighbours.

At first I wanted this to be a place to drop by and not a meeting place as it has become. When I decided to open here I had many problems. In August there were a lot of kids, the neighbours began to complain, saying that there was drug dealing here...The religious leaders have accused us of distributing pills, they are very reactionary. They cannot stand our presence, the administrator cannot wait for me to go. In fact, if the kids see that adults look 
at them as bad, they also react rudely. Several of them have been turned in to the police. The brigade arrived, and we were told that we cannot leave bikes in the street, we cannot even play football. The kids cannot even go in the inner courtyard of the building. Those who are boycotting are middle-aged people. (Barriera di Milano, shopkeeper, 33 years old, F)

The opening of the store, one of the few alternatives for young people to the nearby oratory and sports centre, has encountered so many obstacles that the owner has been driven to seek another location in the neighbourhood. Despite the accusations of drug dealing, however, the first visible effect of the presence of the store has been the disappearance of the drug dealers from the street, intimidated by the presence of young people until late at night. The same complaints against the Italian candy store are aimed at African grocery stores. Their clients, with their behaviour, do not fit into the picture of a consolidated social order. In other areas of the city, rather than being hampered, these forms of spontaneous meeting have been supported and promoted by institutions for several years and today struggle less to take root in the neighbourhood.

\subsection{Peruvian Immigrants as the 'Social Problem' of San Paolo}

San Paolo hosts the highest concentration of Peruvian immigrants in Turin. The reasons are manifold: in this area there are many institutions that have greatly facilitated both their initial reception and their professional and residential integration. The San Paolo village has a high concentration of elderly people, a factor that has undoubtedly contributed to the demand for care work favouring Peruvian immigrant women. Latin American immigration in general, and from Peru, in particular, has shown a significant capacity for building support networks. It is important to emphasize the role of women's networks in the development and maintenance of transnational social spaces through remittances sent to the family, access to social services in the host society, and the interweaving of permanent family contacts. Although female migration has never created social alarm in San Paolo, there is concern about the presence of Peruvian youngsters, most of them arriving to be reunited with their families, who are organized into gangs and occupy public spaces in noisy and violent ways.

The behaviour of these young people is denounced by the Peruvian migrants who, having spent more time living in the neighbourhood, consider themselves well-integrated and worry about the weakening of the intergenerational dialogue between parents and children. A 50-year-old woman, who has lived in Turin since 2003 and has two children in Peru, commented on the death of a boy after a fight at a restaurant:

A lot of guys like these do not listen to their parents. In Peru, however, it is not so. These guys do not work, they have grown up far away with their grandparents and uncles and now that they are here their parents are always out of the house and cannot give advice. ... They fought, they were all drunk and beat this guy; they even took a knife and in the end they killed him. But it is also the parents' fault! (San Paolo resident, housekeeper, 45 years old, F) 
The problem of the second generation is one of the most strongly felt issues in the Peruvian community. When talking to some Peruvian young people, their feelings of isolation and loneliness are clear: "We only hang out with Peruvian guys; with Italians we only have relationships in school."

These youngsters often arrived as adolescents and were then quickly labelled as a problematic group. A 20-year-old student, in Turin for 5 years, speaks about his experience in a violent group:

When I was younger, a few years ago, I was part of a violent group. We drank, smoked, and shoplifted. I do not go anymore. My uncle convinced me to come here to an association and leave them alone. Many of those guys already hung out together in Peru and were part of some thugs' group. (San Paolo, student, 20 years old, M)

To address these issues in San Paolo an ad hoc working group was established, in which numerous Peruvian associations, public institutions (schools, police, the Peruvian consulate), and Catholic institutions (San Paolo oratorio) took part. The group sought to understand the problem and organized an educational cooperative. However, the role played by the elderly Peruvians themselves was even more critical. The creation of activities for young people as well as music and dance courses enabled the regulation of the young people from entirely within the immigrant community, which has dissolved the tensions. The young association members have also been entrusted, by the President of the District, with the management of a summer meeting spot with free activities for all citizens.

The successful management of this situation has prevented a circumscribed internal conflict from developing into a much larger conflict between natives and immigrants. This solution was made possible because San Paolo has a much more cohesive policy community than Barriera di Milano.

\section{The Public Baths, the Moroccan Rapper, and the Italian Wood Engraver}

The conflicts in both San Paolo and in Barriera di Milano involve social groups that differ not only on the basis of ethnicity, but also, and especially, by age, and by the use they make of public spaces and neighbourhood services (Vanderbeck 2007). These conflicts are exacerbated when the object of the dispute is public space. The case of the Public Baths of Via Agliè in Barriera di Milano is a significant example in this regard.

The Public Baths are a big red brick building built by the city of Turin in the 1950s. In the period of the great industrial development and massive arrival of the immigrant population, public baths were an essential service to the many families who had no plumbing in their homes. At the end of the 1980s the Via Agliè baths were closed because residents no longer frequented them. However, in 2004 they reopened as demand, stemming mainly from recent and young immigrants (espe- 


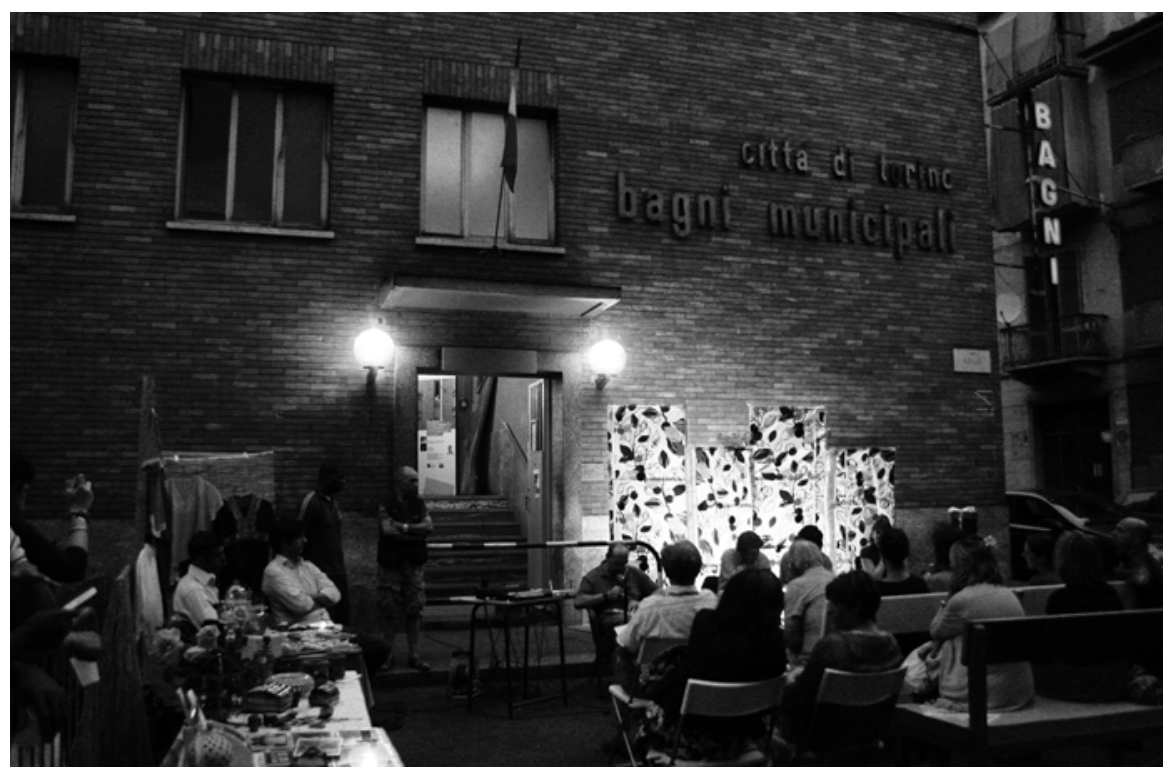

Fig. 8 The public baths of Via Agliè. Exterior (Photo by P. Cingolani)

cially Moroccans), rapidly increased. The image of the baths was by then highly stigmatized and linked to social deviance, so the Italian residents of the area initially protested against it. Word spread gradually and immigrant mothers with children and elderly Italians began to use the baths. This heterogeneity among the visitors normalized the image of the baths. In some cases the use of the baths is routine. In other cases, people use them when they are going through a period of great difficulty, linked to job loss.

The manager and personnel did not just monitor admission, but also listened to the visitors' stories. To meet the visitors' needs for a place to socialize, the reception hall was equipped with chairs and a hot drinks machine. According to a member of the staff:

Many people come here just to be together, to have someone to chat with. We are also a bit like psychologists because we listen.... This is a place where beautiful friendships can also be born between very different people. (Barriera di Milano resident, social worker, 50 years old, M)

The managers of the baths decided to offer a laundry service, which was followed by a tailoring service. On the first floor of the baths a desk was opened to assist people with looking for work, and on the second floor, various associations have exhibition spaces and offices. These spaces constitute a resource for an area of the neighbourhood that suffers particularly from the lack of civic and social life (Fig. 8). 
The practices developed in the baths seem to be successful in healing the rift between the generations and combating prejudice towards foreigners. One of the visitors to the baths is a 76-year-old wood engraver, a native of Piedmont. His workshop is the only one on the street still open, a witness to an almost bygone world of high-quality craftsmanship and manual knowledge. There are often complaints about the presence of young immigrant drug dealers but also about the younger generations' lack of interest in traditional craftsmanship. The wood engraver, who learned his art as an apprentice in a shop close to home, is deeply concerned by the fact that he cannot pass on his skills to his grandchildren because they are not interested in learning them. Within the public baths this man has organized a free restoration workshop, funded by the District and the City. Here he met a 22-year-old Chinese woman from the neighbourhood, who came to Italy with her parents when she was very young. This year she will finish art school and hopes to continue working with wood. The engraver appreciates the deftness and the great patience that she shows in her work. This type of experience, backed by an institutional project, is still sporadic in the neighbourhood, but it clearly represents an interesting form of crossing ethnic and generational lines.

In addition to the wood engraver, a group of young rappers have also used the public baths to cross social divides. This is a group of about 30 young men - Italian, immigrants, and children of immigrants - who met in the streets and gardens of the neighbourhood. They share a passion for music and live in diverse social conditions: some work, some study, some live alone, others live with their families. The baths have free rehearsal rooms, and this is a very convenient alternative to renting expensive private facilities. Thanks to the relationships of trust built over time with the managers of the baths, some of these young men have been entrusted with managing the rehearsal rooms. They also contribute to many of the activities offered to the residents of the neighbourhood, such as festivals on summer evenings. On these occasions, they work as mediators, informing passers-by and shopkeepers of initiatives. A group that is particularly stigmatized in public discourse, as young, aggressive idlers, has thus gained currency in the eyes of many residents, reducing the perceived distances.

In the gardens we improvise, we do free-style, in the afternoon and evening, where the fountain is. If we then have to rehearse we come here. Free-style is an exercise for the head, it's like a workout for football players, which brings together Italians and foreigners. .... Rap is a way to let off steam, to say what we feel inside, to figure out what you like and what you dislike. Not everyone has had the same childhood, not everyone has the same ideas of the future. The common goal, however, is to externalize the suffering, to say that we are angry. The Italian seniors see us as bad, from a distance they think we do who knows what. Now that we are here at the baths, we also have some responsibility and for this we are also more accepted. (Barriera di Milano, rapper, 21 years old, $\mathrm{M}$ )

Many of these young people have strong roots in the neighbourhood, either because they were born here, or because they arrived when they were very young. In their lyrics they sing about the difficulties of living in Barriera di Milano but also their pride in it and have made belonging to this area their hallmark. 


\section{Barriera di Milano and San Paolo: So Near, Yet So Far...}

Barriera di Milano and San Paolo have both similarities and differences. They both developed outside of the city's duty boundaries over the course of the nineteenth century as a consequence of the industrialization process. In both neighbourhoods, the presence of large factories and specific housing opportunities was a pull factor for large immigration influxes from other Italian regions during the economic boom of the late 1950s and 1960s. In both areas, the social composition of the resident population, made up mostly of workers and immigrants, fostered the development of a common cultural and social background, promoting a strong sense of belonging to the neighbourhood. These common features encouraged mobilizations in order to obtain better working and living conditions and sustained intense civic participation and association forming. At the same time, they stimulated public and religious service providers to develop innovative responses, leaving a legacy that is still visible today.

Since the 1970s both neighbourhoods have undergone deindustrialization processes and the factories located there have closed or moved out of the city, whereas the importance of the service sector has increased. This process has generated both challenges and opportunities. San Paolo has showed a greater capacity to take hold of the opportunities associated with the post-Fordist transition.

Barriera di Milano is indeed more socially disadvantaged: its share of poor families, individuals dependent on social services, and those with employment difficulties is higher than in San Paolo and the average education level is lower. Furthermore, services are inadequate and unevenly distributed within the neighbourhood. From an urban perspective, most of the abandoned areas are still there, representing obstacles to mobility within the neighbourhood and contributing to urban blight and a sense of insecurity among residents. Sociability is also hampered by the lack of spaces: meeting places and green areas are insufficient and the demand for room for cultural, recreational, and social activities cannot be satisfied. On the contrary, most of the vacant areas in San Paolo have been reconverted into service, office, commercial, and residential units contributing to the improved endowment of welfare services, meeting places, and the cultural supply of the neighbourhood. Furthermore, the economic transition has not generated such severe consequences in San Paolo, probably also thanks to the stronger cultural and social capital of the resident population.

It is thus evident that international immigration in the two neighbourhoods has interacted with two different contexts and has therefore produced different effects on inter-group relations. Urban blight, being more marked in Barriera di Milano, attracts more immigrants who are looking for cheap apartments, thus favouring segregation processes. However, the very presence of foreign residents is often regarded as the cause of urban blight rather than the other way around. The economic decline of Barriera di Milano has intensified the process in which traditional small shops and crafting activities are rapidly being replaced by ethnic businesses, contributing to the diffusion of a 'sense of invasion.' The shortage of welfare services and meeting 
places seems to reinforce competition with immigrants, which is made harsher by the social weakness of natives who tend to compete for the same jobs, services, and spaces the immigrants ask for.

In light of this general framework, we have demonstrated that integration is a situated and lived experience, the product of the balance between different factors. Within the same area there are places where people live together apart and places in which people conflict. These conflicts are not always between natives and immigrants, but often between groups of people with different ages. Conflict resolutions depend on the presence of individuals who are able to mediate, as was the case with the Via Montanaro gardens in Barriera di Milano or with Giardini SPA in San Paolo. Mediation works well when there is a bottom-up approach, which is implemented by people living in the territory, such as the elderly members of the Peruvian Community or mentally ill persons employed by the local association. In order to produce an enduring change in the neighbourhoods, the initiatives spontaneously generated from below need to be supported by local institutions, as was the case with the public baths. This is a place where the diversification of the differences is not a threat but a value for the area and it can become a replicable practice elsewhere.

Despite these differences, both neighbourhoods seem to benefit from the strong identity and social cohesion that flourished during the industrial development, so that conflictual inter-group relations have thus far been channelled into organized solutions promoted by local institutions or citizens. Nevertheless, the leeway for managing antagonistic dynamics through formal and informal mediation seems to be decreasing due to the economic transition, the current crisis, and social changes.

Open Access This chapter is distributed under the terms of the Creative Commons AttributionNoncommercial 2.5 License (http://creativecommons.org/licenses/by-nc/2.5/) which permits any noncommercial use, distribution, and reproduction in any medium, provided the original author(s) and source are credited.

The images or other third party material in this chapter are included in the work's Creative Commons license, unless indicated otherwise in the credit line; if such material is not included in the work's Creative Commons license and the respective action is not permitted by statutory regulation, users will need to obtain permission from the license holder to duplicate, adapt or reproduce the material.

\section{Bibliography}

Akkar Erkan, Z. M. (2007). Public spaces of post-industrial cities and their changing roles. $M E T U$ JFA, 24(1), 115-137.

Altman, I., \& Low, S. (Eds.). (1992). Place attachment. New York: Plenum Press.

Ascolto, Attivo s.a.s., \& Zaltron, F. (Eds.). (2010). Barriera mobile. Infrastrutture e qualità della vita del quadrante Est-Nord-Est di Torino. Rapporto Finale: Turin. 
Beraudo, G., Castrovilli, A., \& Seminara, C. (2006). Storia della Barriera di Milano dal 1946. Turin: Associazione Culturale Officina della Memoria.

Berg, M. L., \& Sigona, N. (2013). Ethnography, diversity and urban space. Identities, 20(4), 347-360.

Brettel, C. (2000). Theorizing migration in anthropology. In C. Brettel \& J. Hollifield (Eds.), Migration theory (pp. 97-136). New York/London: Routledge.

Cancellieri, A., \& Scandurra, G. (Eds.). (2012). Tracce urbane. Alla ricerca della città. Milano: Franco Angeli.

Carter, D. (1997). States of grace. Senegalese in Italy and the New European immigration. Minneapolis: University of Minnesota Press.

Caselli, M. (2009). Vite transnazionali? Peruviani e peruviane a Milano. Milano: Franco Angeli.

Castagnone, E., Ciafaloni, F., Donini, E., Guasco, D., \& Lanzardo, L. (2005). 'Vai e vieni'. Esperienze di migrazione e lavoro di senegalesi tra Louga e Torino. Milan: Franco Angeli.

Ceccagno, A. (2007). Compressing personal time: Ethnicity and gender within a Chinese Niche in Italy. Journal of Ethnic and Migration Studies, 33(4), 635-654.

Ciampolini, T. (Ed.). (2007). Barriera fragile. Rome: Ed. Idos - Collana Territorio.

Cooperativa Progest with Settore Periferie e Circoscrizione VI, Tavolo sociale Monte Bianco. (2008). Non c'è Barriera senza Spina. Turin: Città di Torino.

Colosso, F., \& Ordazzo, L. (2009). Borgo San Paolo: Storie di un quartiere operaio. Turin: Graphot.

Donna, S. (2010). Via Monginevro com'era: Storia di una Via e di un Quartiere torinese dai primi insediamenti ai giorni nostri. Turin: Edizioni Piemonte Cultura.

Erel, U. (2011). Complex belongings: Racialization and migration in a small English city. Ethnic and Racial Studies, 34(11), 2048-2068.

Fava, F. (2007). Banlieue de Palerme. Une version sicilienne de l'exclusion urbaine. Paris: L'Harmattan.

Gidley, B. (2014). Integration. In B. Anderson \& M. Keith (Eds.), Migration: A COMPAS anthology. Oxford: COMPAS.

Jalla, D. (1978). Cultura operaia e vita quotidiana in borgo San Paolo. In G. Bertolo (Ed.), Torino tra le due guerre (pp. 2-45). Turin: Musei Civici.

Low, S., Taplin, D., \& Scheld, S. (2005). Rethinking. Urban parks: Public space and cultural diversity. Austin: University of Texas Press.

Martinotti, G. (1993). Metropoli. La nuova morfologia sociale della città. Bologna: Il Mulino.

Pompeo, F. (Ed.). (2012). Paesaggi dell'esclusione. Politiche degli spazi, re-indigenizzazione e altre malattie del territorio romano. Turin: UTET.

Semi, G. (2006). Il ritorno dell'economia di Bazar. Attività commerciali a Porta Palazzo, Torino. In F. Decimo \& G. Sciortino (Eds.), Stranieri in Italia. Reti migranti (pp. 89-114). Bologna: Il Mulino.

Valentine, G. (2008). Living with difference: Reflections on geography of encounter. Progress in Human Geography, 32(3), 323-333.

Vanderbeck, R. (2007). Intergenerational geographies: Age relations, segregation and reengagements. Geography Compass, 1-2, 200-221.

Wallman, S. (2003). The diversity of diversity: Implications of the form and process of localised urban systems. FEEM working paper KNOW 76.2003, www.feem.it/web/activ/_wp.html

Webster, C. (1996). Local heroes: Violent racism, localism and spacism among Asian and white young people. Youth and Policy, 53, 15-27.

Wimmer, A. (2004). Does ethnicity matter? Everyday group formation in three Swiss immigrant neighbourhoods. Ethnic and Racial Studies, 27, 1-36.

Wood, P., \& Landry, C. (2007). The intercultural city: Planning for diversity advantage. London: Routledge. 